\title{
S103T3 pattern leading to early diagnosis of pulmonary embolism
}

\author{
Lokesh Shahani \\ Department of Internal Medicine, Southern Illinois University School of Medicine, Springfield, Illinois, USA
}

Correspondence to Dr Lokesh Shahani, lokesh83@hotmail.com

\section{DESCRIPTION}

Acute pulmonary embolism (PE) is common, however, being a fatal disease prompting early diagnosis and treatment to prevent mortality. However, the varying clinical picture makes diagnosis difficult. The author reports a 56-year-old paraplegic man who presented with acute dyspnoea and discomfort in the chest. The patient had recently discontinued his anticoagulant use for prevention of venous thromboembolic disease. The ECG showed the finding of sinus tachycardia along with $S$ wave in lead I, $\mathrm{Q}$ wave and inverted $\mathrm{T}$ wave in lead III which has been associated with acute massive PE causing cor pulmonale (figure 1). ${ }^{1}$ Though not sensitive, this raised the suspicion $\mathrm{PE}$ and considering the clinical picture a CT pulmonary angiography was ordered that showed extensive thromboembolic disease in the bilateral main pulmonary arteries extending to the lobar and segmental pulmonary arteries. An echocardiogram demonstrated significant right ventricular and atrial enlargement with right ventricular dysfunction and strain pattern. Considering the clinical picture the patient was a candidate for fibrinolytic therapy and had a favourable outcome.

Petruzzeli studied ECG abnormalities in patients with suspected PE and found PR displacement; late R in avR, slurred $\mathrm{S}$ in $\mathrm{V} 1$ or $\mathrm{V} 2$, the S1O3T3 pattern and $\mathrm{T}$ wave inversion in V1 or V2 were significantly more common in patients with confirmed PE. ${ }^{2}$ Further, Nazeyrollas et al found only an $\mathrm{S}$ wave in I and $\mathrm{Q}$ wave in III significantly more common among those with confirmed PE. Recognising these ECG findings could prompt clinicians to consider PE and lead to earlier diagnosis of the same.

\section{Learning points}

- Acute pulmonary embolism (PE) is a fatal disease, and early diagnosis and treatment are indicated to prevent mortality.

- ECG abnormalities in such as PR displacement; late R in avR, slurred $\mathrm{S}$ in V1 or V2, the S103T3 pattern and T wave inversion in $\mathrm{V} 1$ or $\mathrm{V} 2$ are significantly more common in patients with confirmed PE.

- Recognising the ECG findings could prompt clinicians to consider PE and lead to earlier diagnosis of the same.

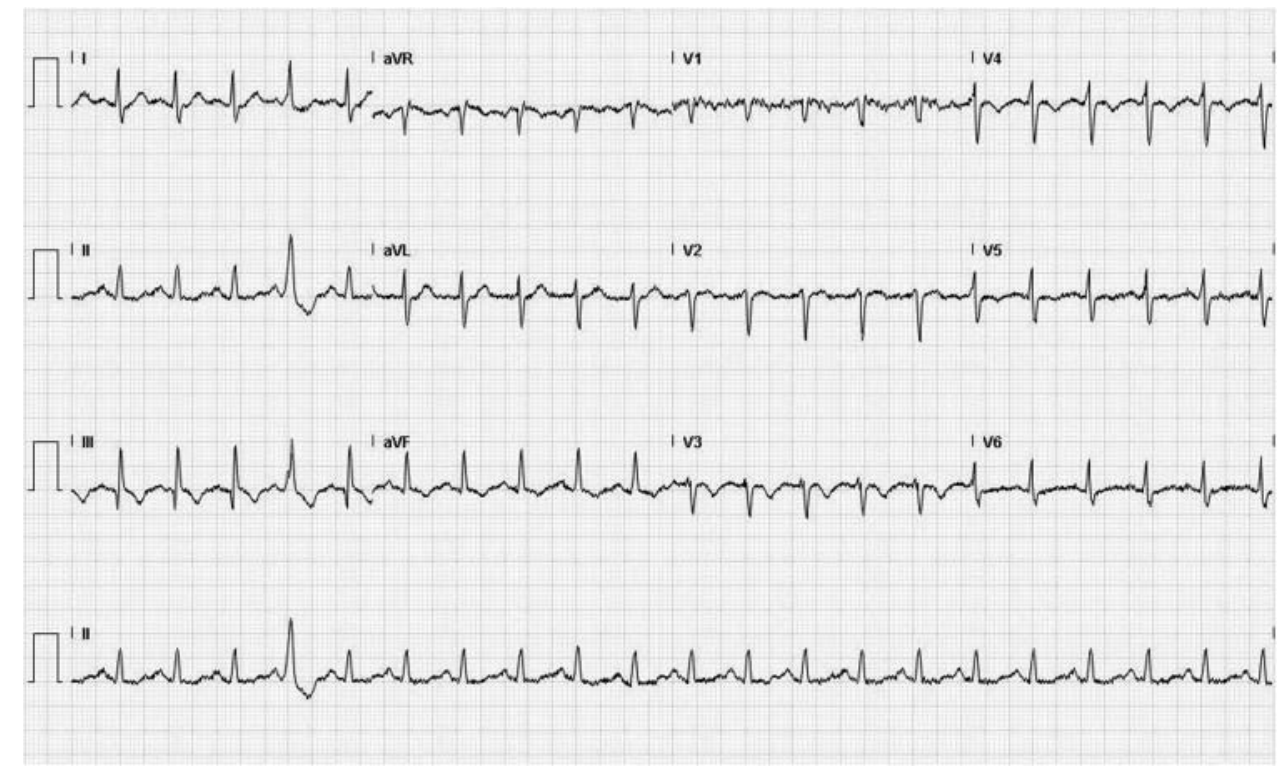

Figure 1 ECG showing an S wave in lead I, 0 wave and an inverted T wave in lead III. 


\section{BMJ Case Reports}

\section{REFERENCES}

1. McGinn S, White PD. Acute cor pulmonarly resulting from pulmonary embolism. JAMA 1935;104:1473-80.

2. Petruzzelli S, Palla A, Pieraccini F, et al. Routine electrocardiography in screening for pulmonary embolism. Respiration 1986;50:233-43.
3. Nazeyrollas P, Metz D, Jolly D, et al. Use of transthoracic Doppler echocardiography combined with clinical and electrocardiographic data to predict acute pulmonary embolism. Eur Heart J 1996;17:779-86.

This pdf has been created automatically from the final edited text and images.

Copyright 2012 BMJ Publishing Group. All rights reserved. For permission to reuse any of this content visit http://group.bmj.com/group/rights-licensing/permissions.

BMJ Case Report Fellows may re-use this article for personal use and teaching without any further permission.

Please cite this article as follows (you will need to access the article online to obtain the date of publication).

Shahani L. S103T3 pattern leading to early diagnosis

of pulmonary embolism. BMJ Case Reports 2012;10.1136/bcr-2012-006569, Published XXX

Become a Fellow of BMJ Case Reports today and you can:

- Submit as many cases as you like

- Enjoy fast sympathetic peer review and rapid publication of accepted articles

- Access all the published articles

- Re-use any of the published material for personal use and teaching without further permission

For information on Institutional Fellowships contact consortiasales@bmjgroup.com

Visit casereports.bmj.com for more articles like this and to become a Fellow 